\title{
COLUMN
}

\section{The Tooth of Time: Henno Martin}

\section{Paul F. Hoffman}

1216 Montrose Ave., Victoria, BC V8T 2 K4

The anticipated letter announced its arrival with colourful geological postage stamps: botryoidal blue willemite $\left(\mathrm{Zn}_{2} \mathrm{SiO}_{4}\right)$ and a cluster of orange wulfenite crystals $\left(\mathrm{PbMO}_{4}\right)$ from Tsumeb, in northern Namibia; placer diamond mining at Oranjemund, mouth of the Orange River which divides Namibia in the south from South Africa (Fig. 1). I had moved to the University of Victoria from GSC six months earlier, and had responded to the NWT MDA-II (1992) call for projects with a proposal to map, with geochronologist Sam Bowring (MIT), the Archean basement rocks of southern Wopmay orogen and the adjacent Indin Lake greenstone belt of Slave craton. How different my future would have been had the proposal not been vetoed in Ottawa. My new academic freedom to work outside the country was now obligatory.

The DNAG (Decade of North American Geology) project had tweaked my interest in Rodinia, the early Neoproterozoic supercontinent, and its partial reincarnation as Gondwana (Hoffman 1991). Andy Knoll at Harvard was drawing attention to emerging carbon and strontium isotope data from Neoproterozoic carbonate rocks, which provide a means of global correlation and suggested a causal relationship between Rodinia breakup and the unusual association of sedimentary

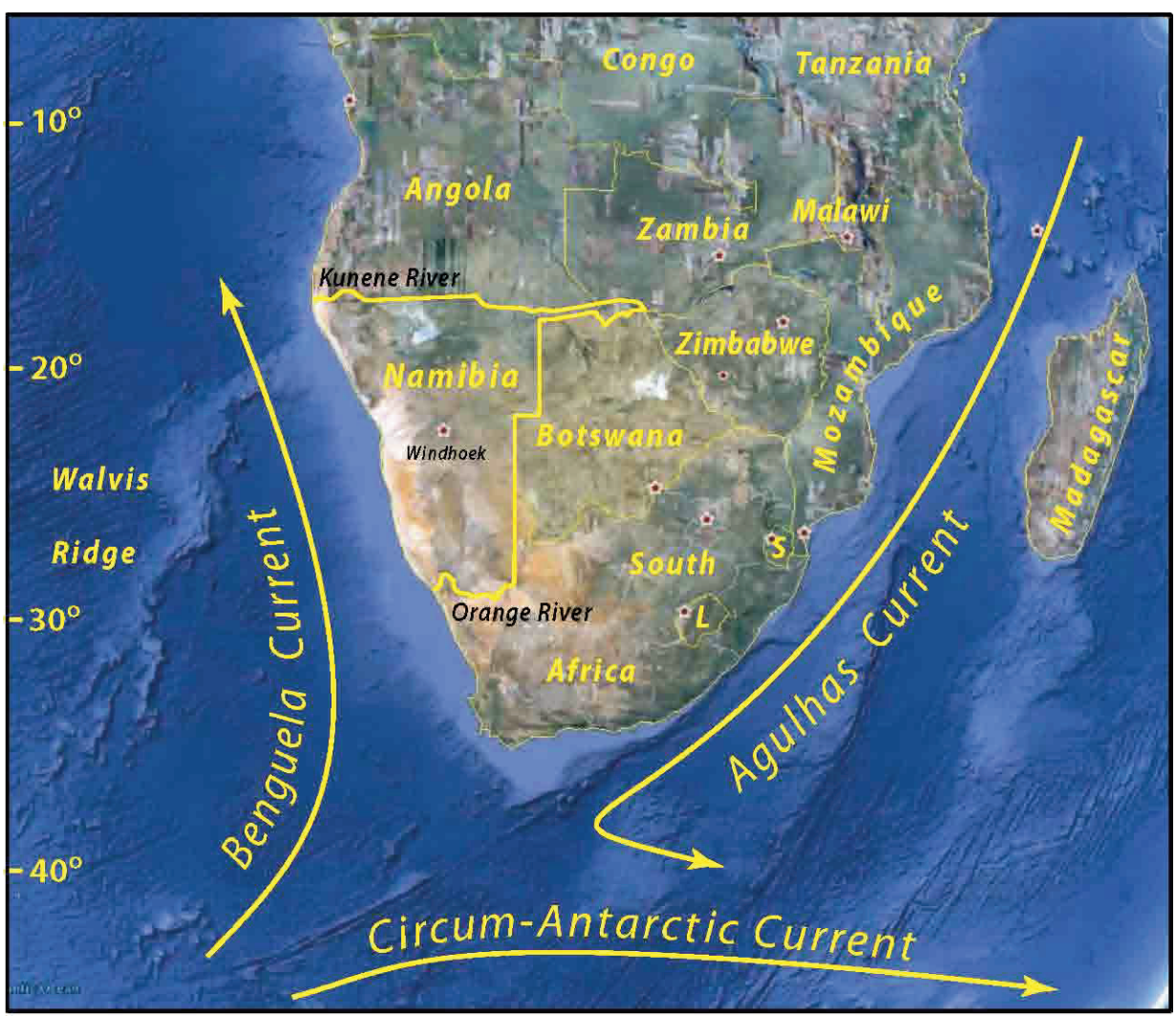

Figure 1. GoogleEarth composite satellite image of southern Africa, showing major ocean currents responsible for climatic asymmetry across the continent.

banded iron-formation (BIF) and glacial diamictite on the one hand, and between Gondwana assembly, increased oxygenation and the radiation of animals on the other (Knoll 1991; Knoll and Walter 1992). John Grotzinger (MIT), who had just begun a project on the latest Proterozoic (Nama Group) in southern Namibia (Fig. 2), suggested that the Geological Survey of Namibia (GSN), eager to encourage mineral exploration after more than 20 years of guerrilla warfare, would welcome a Wopmay-style mapping project in northern Namibia where a 600-km-long fold belt of late (but not latest) Neoproterozoic carbonates, the Otavi Group, hosts the $\mathrm{Cu}-\mathrm{Pb}-\mathrm{Zn}-\mathrm{V}-\mathrm{Ge}$ ore deposits around Tsumeb (Fig. 2).

I had written to the Director of GSN, then Brian Hoal, introducing myself and expressing interest in visiting Namibia with a view to mounting a long-term, mapping-based, research project in the Kaoko Belt, working coastward from the western Otavi Belt (Fig. 2). I explained that I had conduct- 


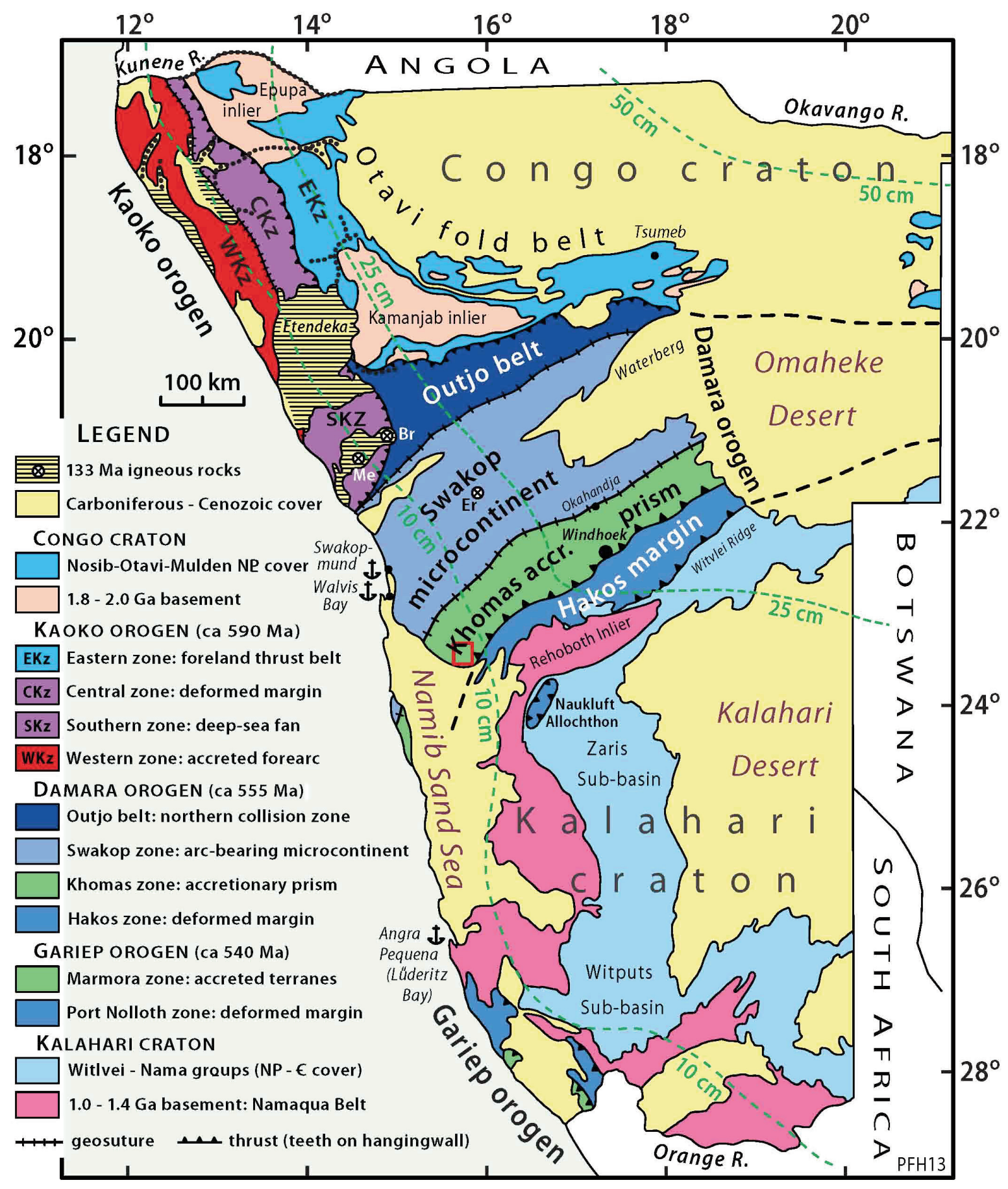

Figure 2. Tectonostratigraphic elements and terranes of Namibia (minus the Caprivi strip), modified after K.H. Hoffmann (1987). Pre-Carboniferous rocks are exposed on the western escarpment, which is a warped Carboniferous glacial surface upon which a Mesozoic sand sea, and Early Cretaceous flood basalt (Etendeka) and felsic intrusive complexes (Br-Brandberg, Me-Messum, Er-Erongo) developed. The Damara orogen joins the Congo craton (Paleoproterozoic) in the north with the Kalahari craton (Mesoproterozoic) in the south. The Swakop zone (Central Damara Zone) is generally considered an extension of the Congo craton, but alternatively it was an independent microcontinent that collided with the Congo craton, after which subduction polarity reversal (Hoffman 2012) led to northward subduction of the Khomas ocean and collision with the Kalahari craton. The Naukluft Allochthon (Korn and Martin 1959) is a tectonic klippe in which different facies zones of the Hakos margin are preserved in a stack of thrust sheets. Heavy dotted black lines are paleovalleys cut by Carboniferous glaciers (Martin 1961). The Etendeka volcanics and associated felsic intrusive complexes are the African homologues of the Paraná large igneous province of southern Brazil, emplaced 8-10 Myr before South Atlantic opening (Eagles 2007). Green dashed lines are contours of average annual rainfall (Mendelsohn et al. 2002). The red box in the Khomas zone is the Kuiseb River canyonland where Henno Martin and Hermann Korn spent over two years in total isolation to escape internment as enemy aliens of military age during World War II. 
ed similar projects in rocks about 1.25 billion years older, albeit with different logistics. I didn't mention that I grew up hearing stories about South West Africa from my uncle Izzy, who owned a tannery there, or that I had dreamed of visiting Tsumeb as a boy, to collect mineral specimens. I didn't mention my secret desire to have been black, my earliest memories of which were watching Jamaicans play pickup cricket in High Park, and listening to a record player for the first time at the home of the only black family I ever knew. Thanks to cold cream and cocao, I was always black on Halloween. I didn't say that I had followed African politics since 1957, when decolonization south of the Sahara began, and also the emergence of African distance runners, ever since Maiyoro Nyandika (Kenya) became the first black African to reach an Olympic distance final a few months earlier (7th at $5000 \mathrm{~m}$ in Melbourne). I didn't mention my 30year love affair with African-American music, or that Namibian Independence Day was my birthday. I also did not mention that I had never set foot in Africa.

I opened Brian's letter, which began, "No need to introduce yourself: your work is well known in Namibia." I knew what he was referring to and I winced. For a time, the aulacogen concept, which I had popularized, was applied to the Damara orogen (Fig. 2), implying that no Neoproterozoic ocean ever existed between the Congo and Kalahari cratons (Martin and Porada 1977a, b; Martin 1983; Porada 1983, 1989). The opposing view ultimately prevailed - the Damara orogen is a collision zone resulting from northward subduction of a Neoproterozoic ocean (Barnes and Sawyer 1980; Kasch 1983; Hoffmann, 1991; Kukla and Stanistreet 1991; de Kock 1992; Miller 2008; Gray et al. 2010) — not least because the basement rocks of the adjacent Congo (2.0-1.7 Ga) and Kalahari (1.3-1.0 Ga) cratons have little in common. The age of the collision is apparently bracketed between $\mathrm{U}-\mathrm{Pb}$ zircon dates of $558 \pm 5$ $\mathrm{Ma}$ (SHRIMP) for arc magmatism in the southern Central Zone (de Kock et al. 2000) and $549 \pm 11 \mathrm{Ma}$ (LAM-ICPMS) for a post-collisional granite in the same area (Johnson et al. 2006). These dates are broadly consistent with the onset of foredeep subsidence around $550 \mathrm{Ma}$ (Nama Group) on the northern Kalahari craton (Grotzinger et al. 1995; Blanco et al. 2009; 2011). The aulacogen concept, as a last refuge for fixism in pre-Mesozoic geotectonics, did no lasting harm. Yet, I could not be happy that it had lured, while in his 60's, the legendary Namibian geologist, Henno Martin.

Henno Martin was born in 1910 in Freiburg, an ancient university and former silver-mining town at the edge the Black Forest - the rift shoulder east of the Rhine graben - in the socially progressive southwest corner of Germany. He raced through school, majoring in natural science and geoscience at the universities of Zürich and Göttingen, before completing his $\mathrm{PhD}$ at age 25 at the University of Bonn (Weber 1998). His thesis adviser was Hans Cloos, himself a Freiburg graduate who loyal readers will remember as Alfred Wegener's only ever geological confidante, 20 years before. Martin's thesis was on Svecofennian (geon 18) tectonics in central Sweden. The influential Swiss geologist Eugène Wegmann had recently shown that the Svecofennian basement in Finland contains Alpine-type nappe structures (Wegmann 1929), supporting J. J. Sederholm's inference from igneousmetamorphic petrology (Sederholm 1907) that Precambrian shields are not the primeval crust, but the worn stubs of ranges different only in age from mountain belts of today (Holmes 1963).

Henno Martin's closest friend in Bonn was Hermann Korn, another Cloos student three years older than Henno. Hermann was born on the north German plain but moved as a child to the Thuringian highlands (Thüringer Schiefergebirge, literally 'slate hills') of central Germany. There, the northwest-plunging nose of the Bohemian crystalline massif exposes, beneath Permo-Triassic cover, a Variscan accretionary complex from the leading edge of Gondwana (Linnemann and Romer 2010), which was oroclinally deformed following its Carboniferous collision with Laurussia (Martínez Catalán 2011). Hermann collected minerals as a child and became the youngest ever member of the Saalfeld Geological Society at age 10
(Korn 1996). Bookish and unathletic, he was probably taunted in school. He suffered episodes of depression all his life, accompanied by heavy drinking, but when he was right he was brilliant. After knocking around different universities, he came under Cloos' wing thanks to his sister, a biologist at the University of Bonn. Cloos himself had problems with depression and encouraged Hermann to consult Henno Martin's father, a clinical psychologist. Hermann's PhD thesis (Korn 1938) was on the structure and sedimentology of a plunging synclinorium of Lower Carboniferous flysch near his home. Among its creative chapters is one on sunspot cycles and the estimation of sedimentation rates. Cloos is quoted as saying that it was the best thesis he ever read, but its completion was a struggle. It is easy to see how Hermann, brilliant but unsteady, was drawn to Henno Martin, quietly resolute and self-disciplined. There were plenty of distractions. Hermann was less politically engaged than Henno, but both were deeply troubled by the turn in German politics.

In January 1933, 25 months into the Great Depression and amid fears of a Bolshevik-style uprising, Adolf Hitler was appointed German Chancellor as head of a coalition government in which his Nazi party held a plurality of seats in the Reichstag. Less than a month later, a mysterious fire in the Reichstag building became the pretext for a decree under which thousands of communist party members were arrested and scores sent to Dachau concentration camp. In March, the Reichstag overwhelmingly granted Hitler's government the power to change any law without parliamentary debate for four years - no parliamentarian wished to be seen opposing the groundswell of public opinion. Noncommunist opposition parties were now forced to disband and in July, when the founding of new political parties was banned, Germany became functionally a one-party state. On the first anniversary of his appointment as Chancellor, Hitler centralized power by transferring state jurisdictions and administration to the federal government, and the selection of mayors to federally appointed officials. Federal secret police, the Gestapo, established 
a network of informers, who conducted surveillance on anti-Nazi criticism and dissent. In the summer of 1934, Hitler quelled unrest within the armed forces, traditionally independent of government, through the assassination of potential military rivals, as well as dissidents within the Nazi party, and by espousing military rearmament as a means of economic recovery. For Henno Martin and Hermann Korn, the rising tide of nationalism, authoritarianism, militarism, paternalism and minority scapegoating, convinced them to seek work abroad. The idea to go to South West Africa was presumably inspired (if not suggested) by Cloos, who had worked there himself as a 25year-old tin-granite exploration geologist in 1910 (Cloos 1954). Henno Martin's father urged Cloos, whom he knew as a former patient, to support his son's decision. In August, 1935, Drs Korn and Martin (Fig. 3) boarded a steamer bound for South West Africa, since 1919 a British mandate administered by South Africa.

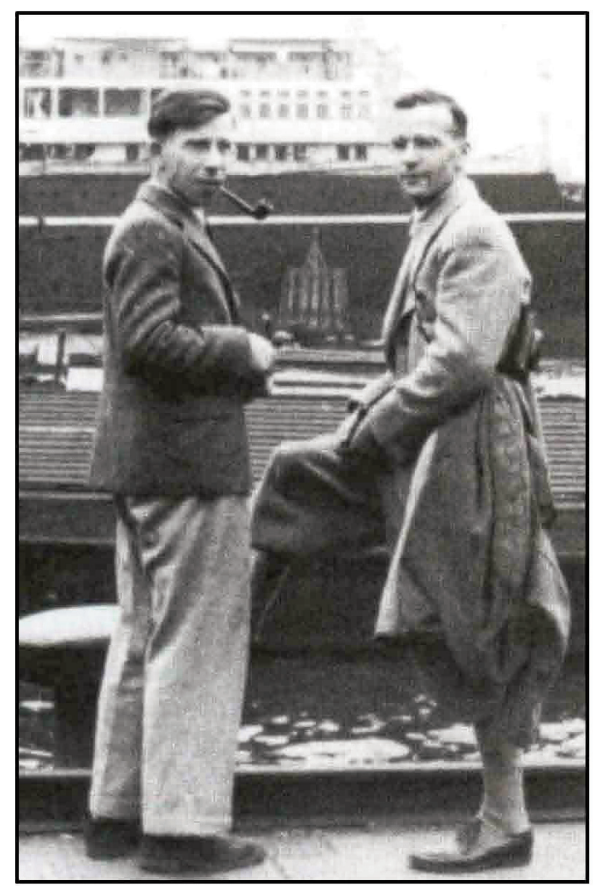

Figure 3. Hermann Korn, 28 (left), and Henno Martin, 25, about to board a steamship bound for South West Africa in 1935.

The German colonization of South West Africa (Namibia) began by surprise and ended in disaster. Otto von Bismarck, the first Chancellor (1871-1890) of a united Germany, had for years resisted lobbying by German missionaries, traders and mining promoters to claim the land between the Orange and Kunene rivers (Fig. 1) as a German protectorate, fearing questionable economic benefits and liberal opposition in the Reichstag. For reasons that elude historians, he abruptly reversed course in 1884 and joined the 'scramble for Africa', claiming Togo, Cameroon, German East Africa (Rwanda, Burundi and mainland Tanzania) and South-West Africa (Namibia) in less than a year (Pakenham 1991). The modern boundaries of Namibia were fixed, at least on paper, by treaties with Britain (1884), which responded by claiming Bechuanaland (Botswana), to prevent German expansion eastward, and with Portugal (1885), which had mapped the coast in the 1480's and was already established in Angola. What the treaties gave the Chancellor was a territory nearly the size of British Columbia, at the latitude of northern Chile (or Mexico). Along its $1,570-\mathrm{km}$-long coastline, only two natural harbours and not a single perennial river exist. The Benguela Current (Fig. 1) drives an Ekman spiral that pushes surface water seaward, generating intense coastal upwelling and productivity. Coastal hyper-aridity derives from intense warming of cold air drawn onshore in summer, and the descent of katabatic easterlies off the high plateau in winter. Rainfall increases with elevation and distance from the ocean, but roughly half of the country receives less than $25 \mathrm{~cm}$ annually (Fig. 2), nearly all in mid-summer (December-January). Most perennial springs are related to local topography. Beyond the barren coastal plain, a rocky escarpment leads to the interior plateau of the Kalahari and Omaheke deserts. The escarpment is relatively steep in the cratonic north and south of the country, but in the area of the Damara orogen it forms a gentle ramp, a natural corridor into the central interior. Residing there since the mid-18th century were an estimated 85,000 seminomadic, Otjiherero-speaking ('Herero' hereafter), cattle raisers (Bridgman 1981). They were centered on the grassy transverse valley between Okahandja and the warm springs around Windhoek, at the foot of mountains marking the deformed Kalahari margin
(Fig. 2). Skirmishes over pasture and livestock with semi-nomadic, Namaspeaking (Khoi Khoi, or 'click' language) tribes from the treeless table lands to the south, intensified in the early 1880's due to drought, both sides armed with rifles purchased from traders in return for cattle. Samuel Maharero, a German-designated representative of the Herero tribes, signed a treaty relinquishing sovereignty over foreign affairs to Germany in exchange for cultural autonomy for his people and personal protection from cattleraiders (Wallace 2011).

The treaty was passionately condemned by Hendrik Witbooi (Fig. 4), foremost of the Nama tribal leaders and a copious correspondent. Both Witbooi and Maharero were Christians, with all the fervour of the recentlyconverted. Meanwhile, a private corporation, the German South West Africa Company (Deutsche Kolonialgesellschaft für Südwest-Afrika), was given a generous concession, including prospecting and mining rights over the entire territory, exclusive rights to build railways, roads,

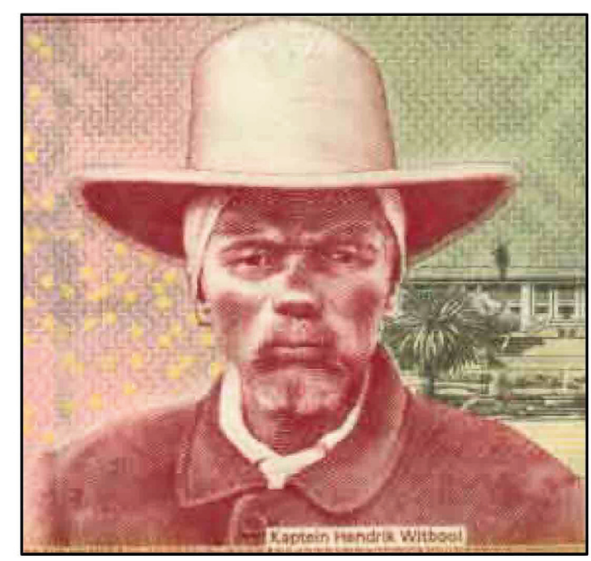

Figure 4. Captain Hendrik Witbooi (1830?-1905), foremost leader among the Nama tribes of southern Namibia during the German colonial period, from the Namibian $\$ 100$ dollar bill. A passionate correspondent, he refused to relinquish sovereignty by treaty with Germany, but kept a verbal (nontreaty) peace agreement with the German Governor, Major Leutwein. After the Herero Revolt, the consequent dismissal of Leutwein and German General von Trotha's genocide of the Herero tribes in 1904, Witbooi led a protracted but ultimately futile guerrilla war against von Trotha until his death in 1905. 
harbours and canals, and to control trade in its areas. Like Bush-CheneyRumsfeld-Wolfowitz, Bismarck believed that nation-building could be left to the private sector. In reality, the South West Africa Company was seriously undercapitalized and little development actually occurred. The size of the German footprint, a small military garrison in Windhoek, coupled with skillful negotiations by the second governor and commander, Major Theodor Leutwein, allowed a fragile equilibrium to exist until 1897. Leutwein's strategy was to exploit divisions within and between the Herero and Nama tribes, and with the estimated 30,000 Namaspeaking Damara people of central African origin on the northern escarpment. Wisely, the powerful Ovambo and Kovango tribes along the northern frontier were not disturbed. Leutwein, educated in law (another Freiburg graduate) but with no prior colonial experience, was exceptional among the German military in his respect for African cultures, and his cynicism regarding the behaviour of German settlers (Pakenham 1991).

In 1897, an epidemic of Rinderpest (a viral infection in even-toed ungulates, which in 2011 became only the second disease after smallpox to be eradicated globally) decimated cattle herds throughout central Namibia. What little vaccine was available was reserved for white cattle ranchers. The Hereros lost $80-90 \%$ of their herds, on top of which an estimated 10,000 impoverished herders lost their lives soon afterwards to typhus (Bridgman 1981). Thousands of former seminomadic pastoralists were forced to take menial jobs from German settlers for bad wages and worse treatment. To make ends meet, they relinquished their best pasture land to white settlers, with Leutwein's approval. The epidemic had also destroyed the oxen used to transport supplies and equipment from the coast. With no private contractor available, the German government ordered the Army corps of engineers to build a railroad linking Swakopmund with Okahandja and Windhoek, employing African labour. The line was completed in 1902 and the German settler population rose sharply (to nearly 5,000$)$ as a consequence. Called 'baboons' to their faces, the Hereros, for whom personal dignity was paramount, seethed in silence and organized. They evidently believed that the German colony, tiny by comparison with others in southern Africa and protected by less than 300 active soldiers, could be driven out altogether (Bridgman 1981).

In January 1904, Leutwein left Windhoek with two-thirds of his forces to put down a Nama tribal rebellion in the far south of the country (Bridgman 1981). The Herero seized the opportunity. Well armed and mounted, they descended without warning on German ranches along the railroad line, killing every adult German male they could find. Within days, military garrisons were under siege. For two weeks, the Herero forces had their way and about 100 German settlers and traders were killed. Women and children, missionaries, and non-German whites (English and Afrikaner) were unharmed (Pakenham 1991). More would have died had reservists not been called up when the colonial office in Berlin got wind of a buying spree by the Herero of saddlery and ammunition. Providentially, 85 marines on coastal patrol by gunboat had been summoned before the telegraph line was cut on the first day of fighting. Leutwein, caught completely off-guard, rushed back to Windhoek with his troops. After securing the garrisons, he moved against the Herero forces in April, but outnumbered and outmaneuvered by fighters accustomed to skirmishes with the Nama, he was soon forced to retreat (Bridgman 1981).

Not surprisingly, the Reichstag was in an uproar, demanding military action. A small revolt in an obscure part of Africa that had never been anything but a drain on the German economy, it was treated like an attack on the homeland itself. Even the Socialists, normally critical of all things imperialistic, were silent. The headstrong young Kaiser, Wilhelm II, having deposed the ageing Bismarck in 1890, now transferred authority from the colonial office to the Army; second largest in the world after the Tsar and itching for action. An expeditionary force of 500 soldiers was ordered to the colony in early May. It was commanded by Prussian General Lothar von Trotha, a veteran of the Austro- and FrancoPrussian wars, who had earned a reputation for ruthless suppression of revolts in China (1890 Boxer Rebellion) and East Africa (1894 Wahehe Rebellion). Upon arrival in Swakopmund in June, von Trotha replaced Leutwein as Commander in the colony (Leutwein remained Governor). The Herero, now outgunned if not outnumbered, withdrew with their families and stolen cattle in stages, finally camping at the foot of the Waterberg (Fig. 2), a plateau of Mesozoic aeolian sandstone, where they sought protection in the length of any German supply line.

Von Trotha, however, was patient as well as ruthless. He methodically encircled the Herero encampment and poisoned the water supply. On October 2, he issued an ultimatum (Schrecklichkeit) ordering all Herero people to leave the country, specifying that Herero men who remained would be executed, and their women and children driven into the desert by gunfire (Bridgman 1981). Slowly tightening the noose, von Trotha deliberately left an escape route to the southeast, through which most of the Herero with their cattle eventually fled, into the Omaheke Desert (Fig. 2). Of the 80,000 Herero alive in 1903, nearly 15,000 had been consigned to prison camps before the October ultimatum; 50-60,000 had survived the battle of Waterberg. Of the latter, fewer than 5,000 made it across the desert to Bechuanaland, to the northern frontier (Ovamboland), or the Nama country in the south. An undetermined number managed to slip back through the German lines, but most were rounded up and killed in a sweep the following year. By late 1904, there were close to 10,000 German troops in the colony. The Hereros had lost their land, their cattle and $75 \%$ of their population.

Witbooi observed the options open to the Herero and their ultimate fate. He had resisted their appeal for military support, true to his non-treaty agreement with Leutwein. He observed that von Trotha was no Leutwein, a man with whom deals could be made. He knew that the German settlers were bent on disarming the Nama tribes entirely. Fatefully, he now decided that hostile action was his only option 
(Bridgman 1981). He counted on the absence of a railroad in the south, on which the German army relied, on guerrilla tactics (unlike the Herero), mandated by the Nama fighters' numerical inferiority (fewer than 1,410 ), and if need be on the adjacent British sanctuaries. Von Trotha and Berlin were dismayed that making an example of the Herero had emboldened, not intimidated the Nama. German public opinion, solidly behind military action months before, was now deeply divided. In April 1905, after months of sporadic fighting, von Trotha marshalled his forces, now climbing toward 15,000 troops, and decreed that all Nama ('Hottentot') people must immediately surrender and give up their arms, or be shot if they did not leave the country. Bounties were offered for tribal leaders, causing those with uncommitted loyalty to side with the Witboois. The fighting dragged on for months: the small and mobile Nama fighting units eluding the German regiments, while raiding their lines of supply. German casualties mounted, as did anti-war sentiment back home. Von Trotha was relieved of his command in October, just as the war against the Nama took a decisive turn.

Hendrik Witbooi was mortally wounded in a raid on a German supply train on October 29. By the end of the summer, March 1906, all the major Nama tribes had surrendered into German custody. Twelve months later, the colony was declared officially pacified and troop level was reduced to 4,000. Of the estimated 20,000 southern Nama before the war, less than half survived. On August 18, 1907, the Colonial Office declared that no native in the colony could own either land or cattle (excepting the Ovambos); all males over seventeen must carry passes; being jobless was a punishable offence; and all natives were subject to forced labour (Bridgman 1981). Whippings by white settlers and government officials became routine. To achieve all this, Germany had sacrificed 2,348 men killed (half by disease), missing and wounded.

In 1908, diamonds were confirmed on the southern coast by Paul Range, a district geologist with the mining commission who also identified the Gibeon meteorites, Carboniferous (Dwyka) tillite and the Ediacara fauna of the Nama Group (Schneider 2000). In diamonds, the colony at last had a profitable export. With increased subsidies for German settlers, the white population grew rapidly from 3,000 in 1906 to 14,000 in 1914. This was the Süd-westafrika that Hans Cloos visited in 1910 (Cloos 1954).

By 1935, when Henno Martin and Hermann Korn set out for South West Africa (SWA), the colony had lost more than its hyphen. On August 4, 1914, the United Kingdom declared war on Germany, in response to German declarations of war on Russia, France and Belgium. The Union of South Africa (the British colonies of the Cape and Natal, and the Boer republics, Orange Free State and Transvaal), as part of the British Empire, was automatically at war with Germany. South African forces invaded German Süd-westafrika and seized control. At the war's end, the colony was formally mandated to Britain, to be administered by South Africa. Under the League of Nations mandate (Article 22), SWA was to be administered as an integral part of South Africa (Wallace 2011). During the 1920 's, the native tribes were parcelled out into reserves, while 'poor white' settlers poured in from South Africa, doubling the white population. By the end of the 1920's, most of the natives in the central and southern areas worked for white land-owners. As in the American Southwest, the first years of the Great Depression brought drought, on top of the collapse of the export market for minerals. However, through most of the 1930's the rains were good and high unemployment in South Africa swelled the immigration rate and land allocations accordingly (Mendelsohn et al. 2002). By 1937, $36 \%$ of the country had been allocated to commercial ranchers (versus $44 \%$ in 2001). It was this surge in private land allocations that enabled Martin and Korn to support themselves as consultants in the siting of water wells after their initial funds ran out. They were well trained in practical geology, and hydrology is a science in which a few general principles and some local knowledge go a long way. The work left them with ample time for their pri- mary objective, the geology of the rocky escarpment (Fig. 2). Mapping together, alone in the desert, was the best of times. Henno later recalled that Hermann was mentally healthiest in the desert because there was always something that needed doing. During this period, before World War II, they worked on the structures which two decades later would make them the envy of geologists around the world. Characteristically, they worked simultaneously on the Precambrian geology, the glacial-bearing Karoo (late Paleozoic) succession, the Early Cretaceous igneous province, and Cenozoic terrestrial sequences and landscape development (Miller and Weber 2000).

They had often joked that if war came, they would hide away in the desert. On Friday September 1, 1939, they heard on the radio that Nazi Germany had invaded Poland. By midday Sunday, the United Kingdom and France had declared war on Germany. The United States declared its neutrality on Tuesday, but earlier in the day when South African Prime Minister Barry Herzog failed to gain support for neutrality in his caucus, he was replaced by Deputy Prime Minister Jan Smuts, who declared war on Germany the following day. At that moment, the two German geologists in SWA became enemy aliens of military age, subject to internment until the war was over. The internment process started slowly, however, and the two did not feel the urgent need to take action until the following winter. They had been working around the Brandberg (Fig. 5), a dome-shaped mass of Early Cretaceous granite $25 \mathrm{~km}$ in diameter, which intrudes an inward-dipping collar of broadly coeval basalt flows, over 1,800 $\mathrm{m}$ below the summit of the intrusion. On May 25, after four days of packing, they left scraps of paper in the trash with tallies of gasolene needed for a return to Brandberg. Then they drove their two vehicles halfway there, before turning off into the hills at dusk. After dark, they slipped off to the southwest on a little-used track heading into the hyper-arid Namib. Driving only at night, for fear of being seen in the open desert from the air, they crossed the Swakop River-loose sand at this time of year-and circled back toward the southeast until they reached a maze 


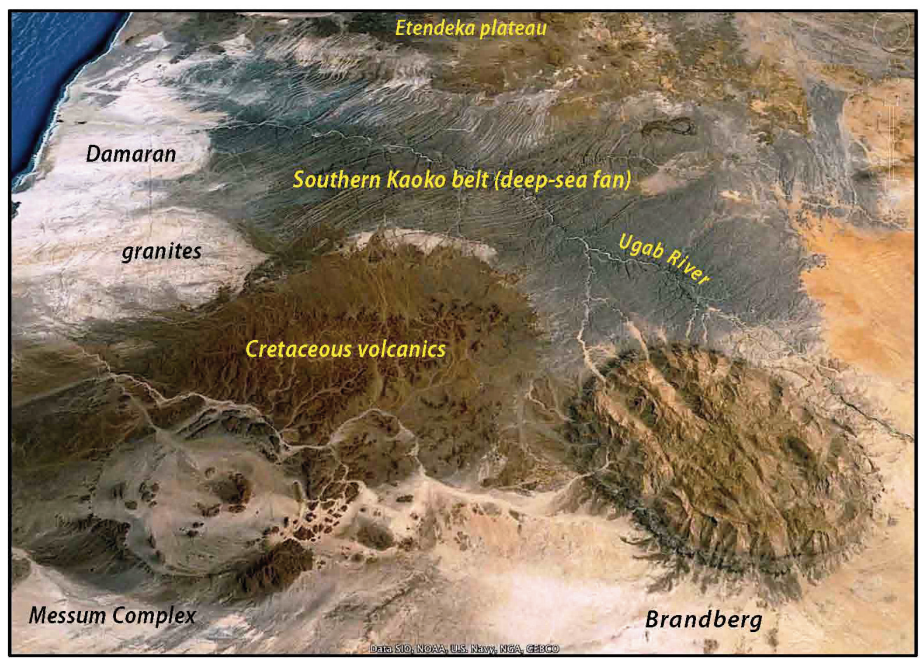

Figure 5. GoogleEarth satellite image looking obliquely north-northwestward at the Early Cretaceous ( 133 Ma) Messum and Brandberg igneous complexes (see Fig. 2 for location). Note the Atlantic Ocean in the upper left. The Messum ring complex (Korn and Martin 1954) is a resurgent cauldron-subsidence structure $20 \mathrm{~km}$ in diameter; the Brandberg (Korn and Martin 1954; Diehl 1990) is a discoidal peralkaline granite body, $25 \mathrm{~km}$ in average diameter, that intrudes an inward-dipping collar (black) of metamorphosed Cretaceous volcanics, $1800 \mathrm{~m}$ below the summit of the granite, which at 2,579 $\mathrm{m}$ above sea level is the highest point in Namibia. In the background, the low ribbed bedrock is a train of west-vergent, 0.8-km-wavelength, folds in the Southern Kaoko Belt (Passchier et al. 2002), developed in Neoproterozoic turbidites of the Zerrissene deep-sea fan (Swart 1992). The fold belt is intruded by post-tectonic (Cambrian) muscovite-tourmaline granites. The turbidites and Damaran granites form a gently-warped Carboniferous glacial surface upon which the Cretaceous igneous rocks were constructed.

of schist-rock canyons in the upper Kuiseb River catchment (Fig. 6). There, they hid their vehicles and for the next two years plus 100 days, they lived in total isolation, connected to civilization only through a short-wave receiver.

They had surrendered their hunting rifles to police at the outbreak of war, leaving them with only a pistol and an air gun, and limited rounds of ammunition. For basic supplies (flour, sugar, tobacco, etc.) and fuel, they had only what they brought with them. They were not alone in the desert and they would learn to catch and trap what they ate. They camped beneath overhangs of Tertiary conglomerate, underlain by tilted schist, but were forced to move repeatedly in the canyonlands as their water holes dried up (Figs. 7-9). To keep their spirits up, they had Otto, their dog. 'The Sheltering Desert' (Wenn es Krieg gibt, gehen wir

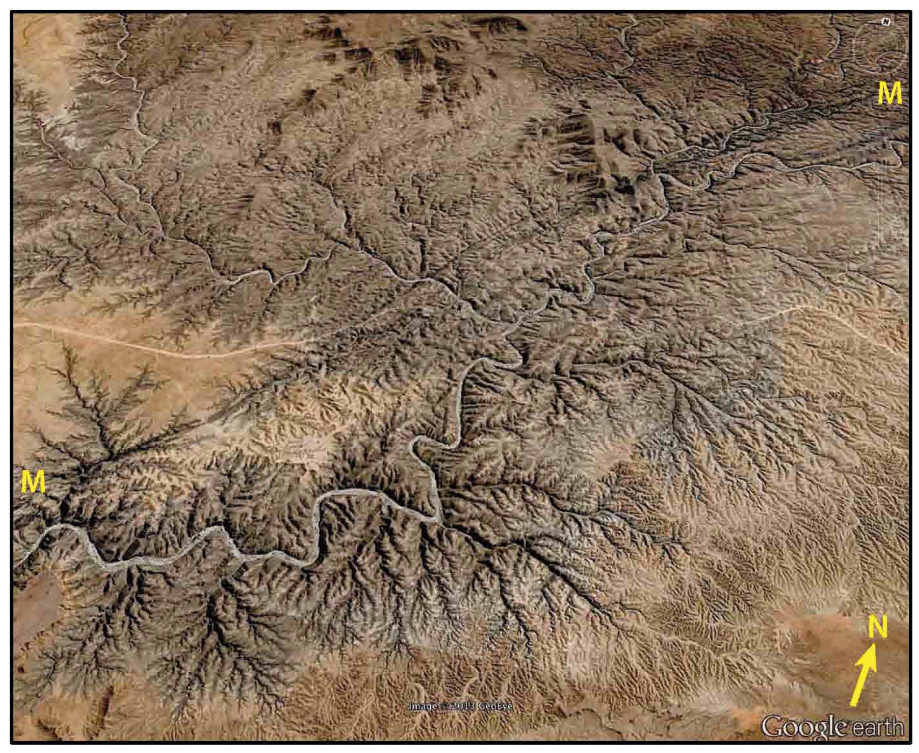

Figure 6. Barren canyonlands of the upper Kuiseb River (see Fig. 2 for location), where Henno Martin and Hermann Korn lived in total isolation for over two years to escape internment as enemy aliens. The scene is $25 \mathrm{~km}$ across in the middle ground. They entered the area from the northwest along a track close to the modern road (pale line) from Walvis Bay to Solitaire. The canyons are cut into northwest-dipping metasedimentary schist of the Khomas accretionary prism (Fig. 2). The darker bands (M) running from lower left to upper right are composed of MORB-like volcanic and intrusive rocks of the Matchless amphibolite (Miller 1983c, 2008).

in die Wüste in the original German), describing their experience, was written by Henno for his wife, whom he met in Germany after the war. Translated into dozens of languages, it has rarely if ever been out of print in English since its first publication in 1957 (Martin 2012). Toward the end of their second winter, Hermann became seriously ill with beri-beri. On September 2, 1942, Henno drove him to Windhoek and then returned with Otto to the desert by the original circuitous route, to await the arrival of the police. Arrested by a well-armed detachment, he spent two days in jail and two weeks in isolation in hospital, before Hermann was well enough for them to face a magistrate, charged with a long list of minor offences. They were assessed a small fine, paid by friends, and released. Before the end of the war, they were hired by the government to conduct groundwater exploration (Schneider 2000).

Hermann Korn died in a sin- gle-vehicle accident just outside Windhoek in 1946. The following year, Henno was appointed director of the SWA branch of the South African Geological Survey, a position he held until 1963 (Schneider 2000). It is all the more remarkable, therefore, that he managed to write up the sensational geology he had done with Korn before the war (Korn and Martin 1954, 1959). Their first project, suggested by Cloos, had been to map the Naukluft Allochthon (Fig. 2), an enormous klippe containing a stack of stratigraphically and structurally distinct nappes (Figs. 10-11). They interpreted the nappes as giant submarine landslides (like those in the Namibian offshore subsurface, Butler and Paton 2010), based on the occurrence of a planar unconformity, overlain by an undeformed dolomite bed, between two of the major nappes (Korn and Martin 1959). This "unconformity dolomite" later proved to be a tectonic mylonite, implying that the nappes are tectonic in origin and were transported from different facies zones of the ancient Hakos continental margin 


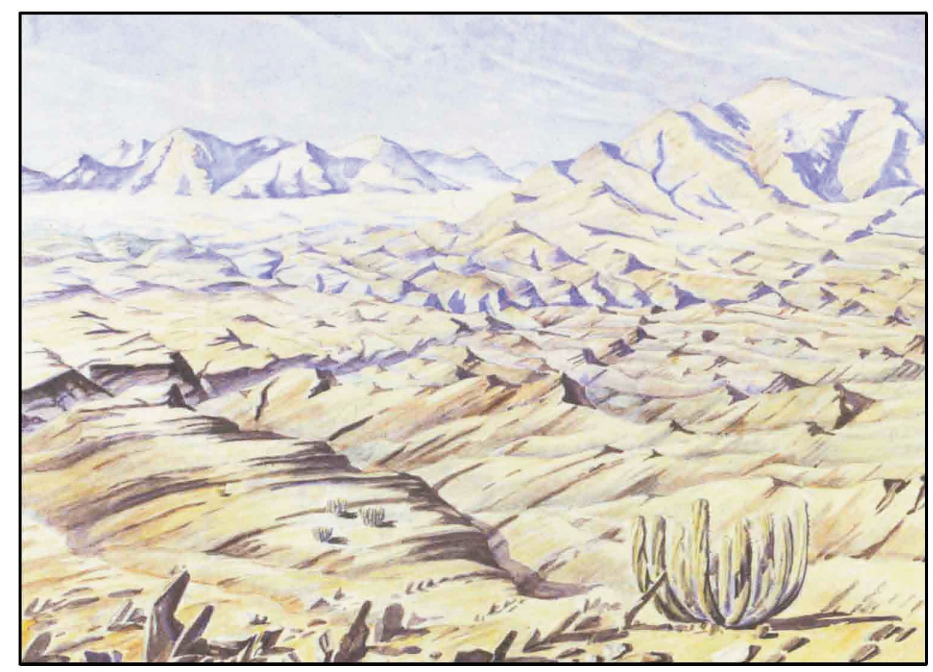

Figure 7. Watercolour by Hermann Korn of the view looking north toward the Goagas Mountains from the roof of their first campsite at Carp Cliff, near the center of Fig. 6. Note the northwest-dipping foliation of the Khomas schist and the dark band of Matchless amphibolite running from middle left to upper right. Painted on location between June 1940 and January 1941 according to Henno Martin (reproduced from Korn 1996).

(Martin 1974; Münch 1978; Hartnady 1978; Martin et al. 1983; Hoffmann 1989). Thus the allochthon has greater significance and value than originally conceived. Their second major discovery was the Messum igneous complex (Fig. 5), a 20-km-diameter cauldronsubsidence structure comparable to Glen Coe (Devonian) in Scotland (Clough et al. 1909; Kokelaar and Moore 2006) or Valles (Pleistocene) in New Mexico (Smith and Bailey 1968; Bailey et al. 1969). As with the Naukluft Allochthon, Henno's elaborate cutaway block diagrams of Messum cauldron, accurately projected from detailed maps, symbolize the wealth of information about crustal processes obtainable from surface mapping in areas of exceptional exposure (Korn and Martin 1954, 1959). The Naukluft and Messum papers were written on weekends, or while on-leave. Aside from administration, Henno's primary mandate was the hydrological survey of the country, but in characteristic fashion he mapped the bedrock at the same time, culminating in the first 1:1M scale geological map of Namibia (Schneider 2000).

Henno's unique knowledge of the Karoo succession in SWA led to his appointment as a visiting professor at the University of São Paulo (Brazil) orogen conform in 1958-60. He had recognized that the Karoo deposits delineate paleovalleys (Fig. 2), commonly occupied by modern rivers, that were excavated by westward-flowing Carboniferous glaciers or ice streams (Figs. 12-13), and that the present landscape, wherever pre-Karoo rocks are exposed, is essentially a Carboniferous glacial surface (Martin 1953, 1968a). This explains why the Cambrian granites of the Damara to the general warped peneplain, while Cretaceous granites make the tallest mountains

in the country (Fig. 5). (Having lived and worked in glacial landscapes nearly all my life, it never occurred to me when I went there that the Namibian

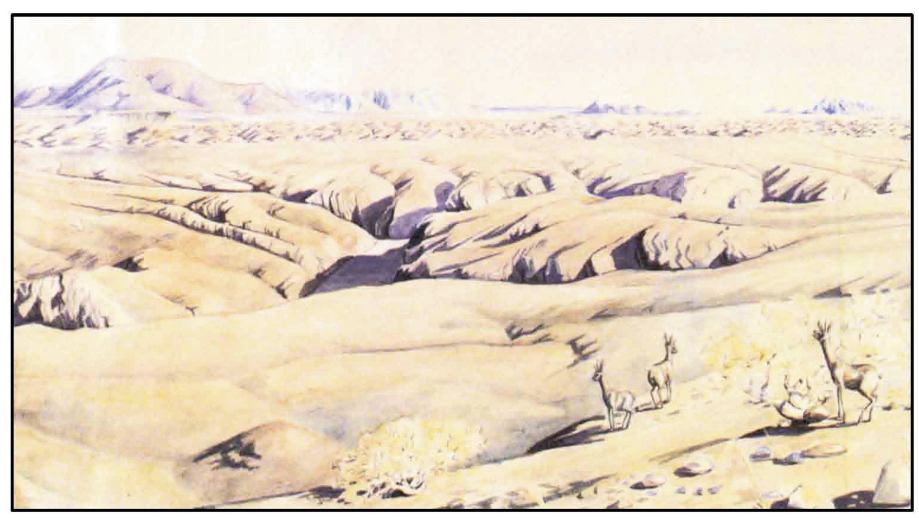

Figure 8. Watercolour by Hermann Korn from the same location as Fig. 7, looking southeast across the Kuiseb River main canyon toward Rostock Mountain, a parautochthonous basement massif within the outer Hakos margin (Fig. 2) zone of the Kalahari craton (Hoffmann 1983). Klipspringers (Oreotragus oreotragus) in the right foreground are small antelope about $0.5 \mathrm{~m}$ high at the shoulder. Painted at location (Korn 1996).

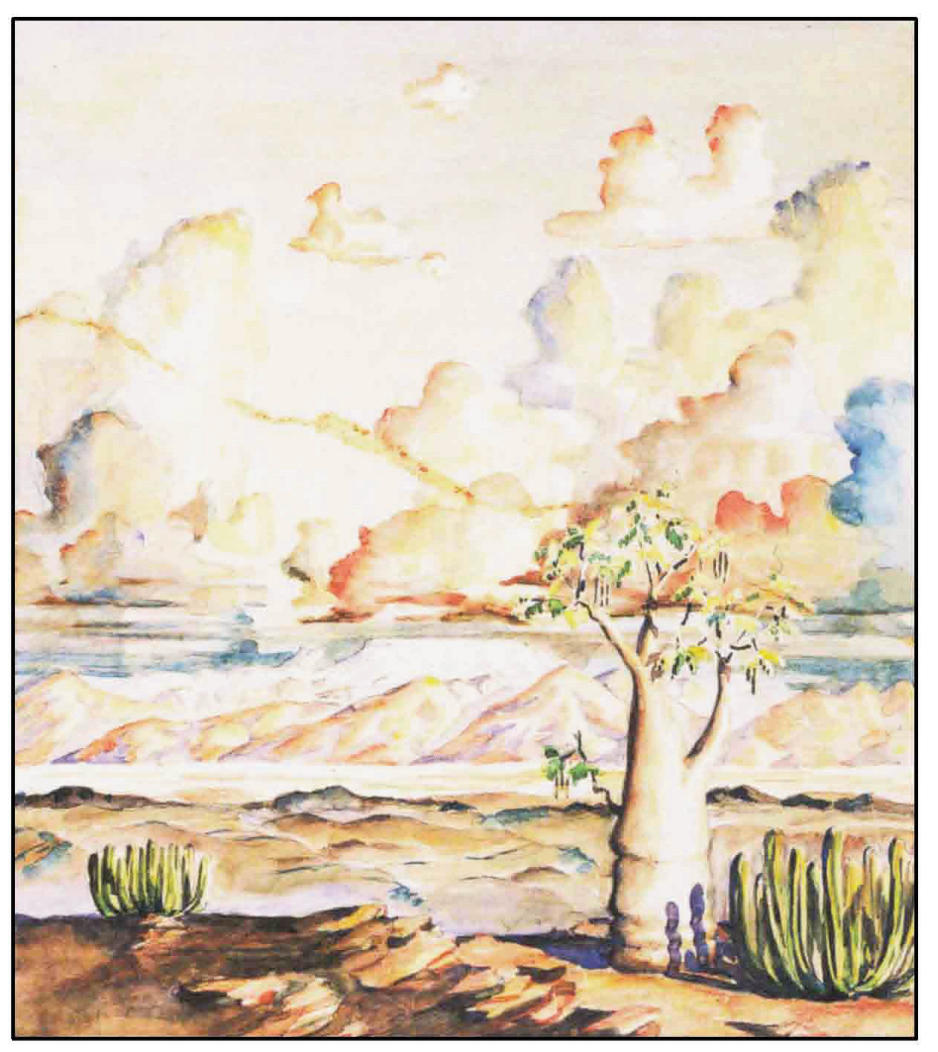

Figure 9. Watercolour by Hermann Korn from a location about $5 \mathrm{~km}$ upstream from the previous (Figs. 7 and 8), looking southeast toward the Gamsberg Mountains in the Hakos margin zone (Fig. 2). Cumulus development is a summer phenomenon. Edible Moringa tree (Moringa ovalifolia) and poisonous Euphorbia plants in foreground. Painted at location, February-March 1941 (Korn 1996).

landforms were abnormal.) During his two years in South America, Henno was able to compare the Karoo successions with those in SWA, strongly sup- 


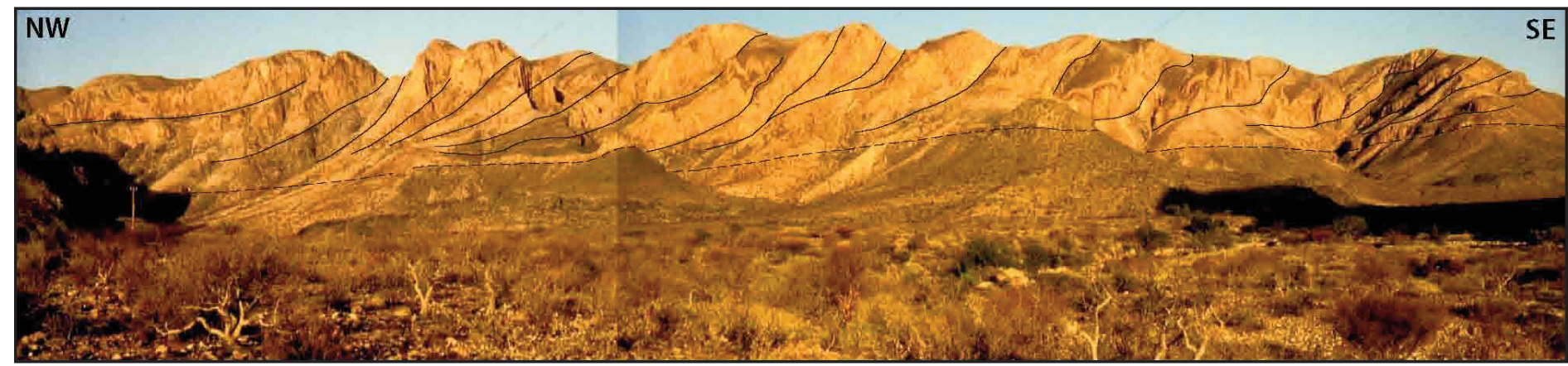

Figure 10. Thrust duplex within the Dassie nappe in the southwest of the Naukluft Allochthon (see Fig. 2 for location). Northwest-dipping thrust faults (solid lines) appear to sole in the 'unconformity dolomite' (broken line), which discordantly overlies parautochthonous lower Nama Group (Schwarzkalk Formation) limestone (Korn and Martin 1959).

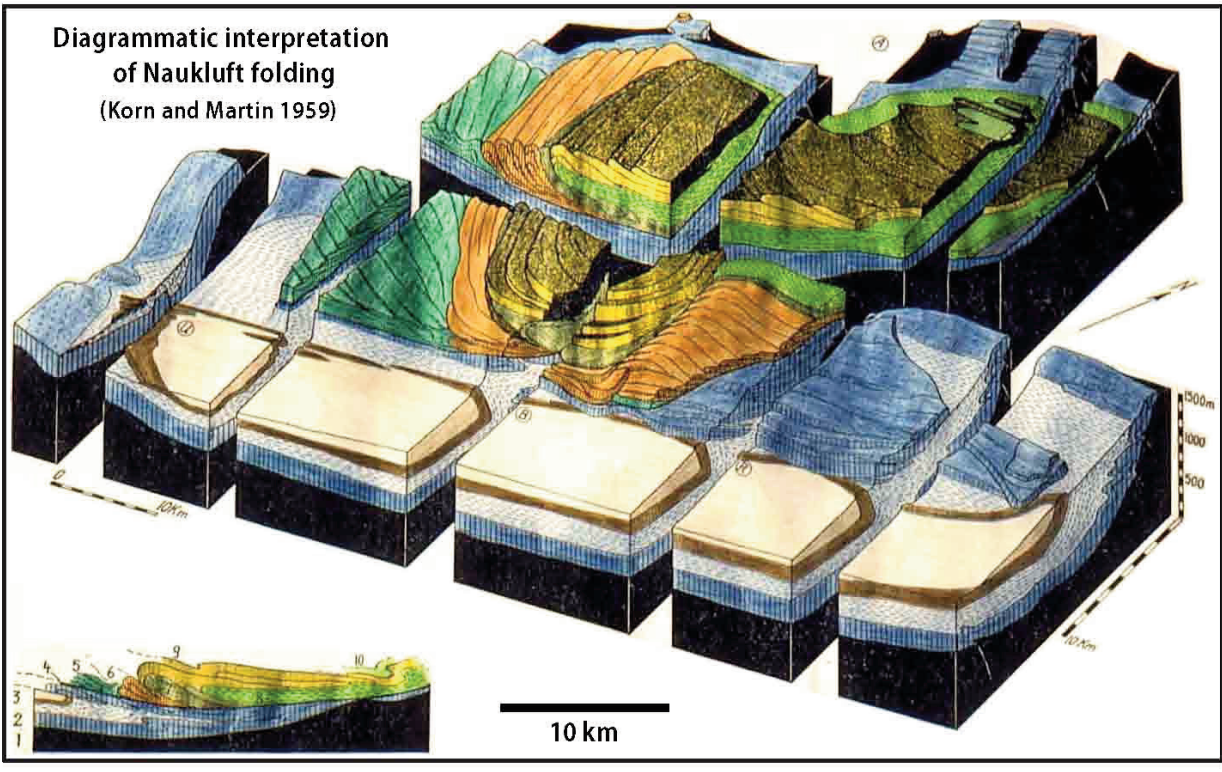

Figure 11. Diagrammatic interpretation of folding within and beneath the Naukluft Allochthon, looking toward the northwest (hand coloured after Korn and Martin 1959). The allochthon is an erosional remnant (klippe) of a thrust sheet derived from the Hakos margin zone (Fig. 2). Colour code: black - autochthonous basement (Kalahari craton); blue - autochthonous and parautochthonous lower Nama Group (Schwarzrand and Schwarzkalk formations); dark green - Zebra nappe; orange - Dassie nappe (see Fig. 10); light green - Pavian nappe; yellow - Kudu nappe.

porting the hypothesis that Carboniferous ice had flowed directly off southern Africa onto southern South America (du Toit 1927, 1937). He also determined that Mesozoic wind directions had been the same on both sides of the South Atlantic, as if the ocean were non-existent. Henno's outspoken support for continental drift (Martin $1961,1968 b, 1981)$ happened to coincide with its rebirth, in the revised form of plate tectonics. It came from the geology, not from Hans Cloos, who tolerated but never accepted Wegener's ideas.
In early 1963, Henno heard the call of academia and became director of the Precambrian Research Unit at the University of Cape Town (South Africa). He was 53 and had lived in SWA for 28 years (he would continue to do field work there for 24 years more). During his two years in Cape Town, he completed arguably his most important contribution to SWA geology (Martin 1965a). The Precambrian Geology of South West Africa and Namaqualand is a systematic synthesis of preKaroo, stratigraphic and economic geology. It came at a time of renewed interest in Neoproterozoic glaciation (Harland 1964a, b; Harland and Rudwick 1964), yet the glacial origin of 'tilloids' in the Neoproterozoic of southwestern Africa was being actively challenged by advocates of nonglacial mass-flow processes (Schermerhorn and Stanton 1963). Henno responded forcefully that a glacial origin was well supported in southern Namibia by mixtites carrying faceted and striated clasts and erratic boulders, by laminated mudstones with rafted dropstones, and by a pavement with multiple sets of grooves. He argued that a glacial origin was highly probable for the mixtites of central and northern Namibia which occur at comparable stratigraphic horizons (Gevers 1931; le Roex 1941), because non-Alpine glaciation is a regional and time-dependent phenomenon (Martin 1965a). A number of sub-economic iron-formations had been identified in SWA during the post-war exploration boom and Henno had recognized their intimate association with Neoproterozoic glacial deposits. He suggested that this "peculiar combination of sediments" could be accounted for by anoxia due to prolonged ice cover on silled basins (Martin $1965 \mathrm{a}, \mathrm{b})$. He correctly inferred that active faulting persisted in northern SWA until the upper part of the Otavi Group carbonate succession (Martin 1965a, p. 40). More broadly, he noted that the Damara 'geosyncline' branches off from the western coastal belt of southern Africa and may, or not, continue in the subsurface into the Katanga geosyncline, which branches off the eastern coastal belt (Fig. 14). Regarding the Damara belt itself, he wrote (ibid., p. 126): "It is of great theoretical interest 


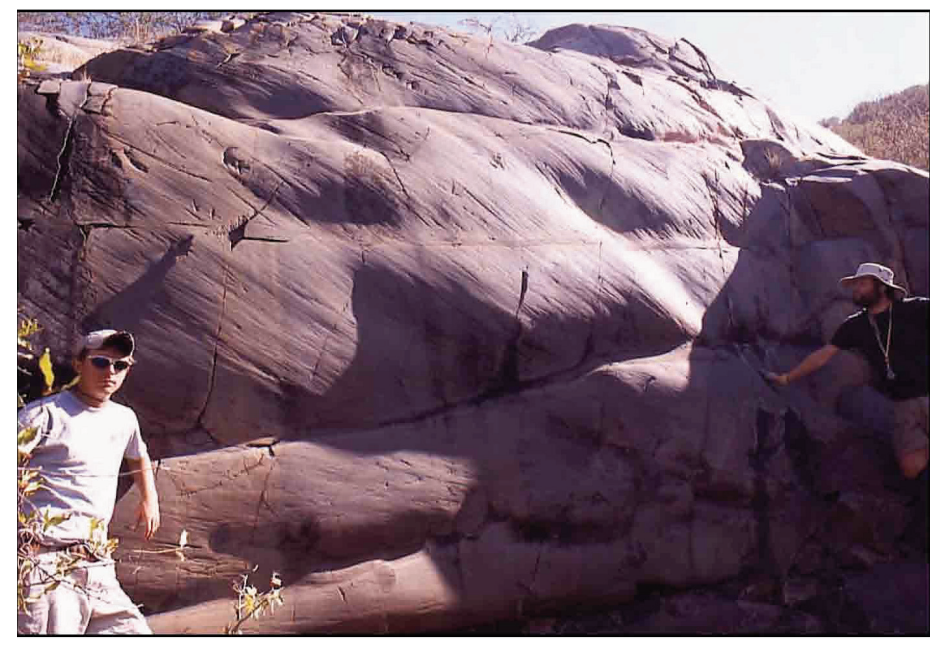

Figure 12. Carboniferous glacial striations on outcrop of subhorizontal Proterozoic quartzite (Nosib Group) near Orotjitombo, $20 \mathrm{~km} \mathrm{NW}$ of Opuwa in the Eastern Kaoko zone (Fig. 2) at 1759'08's, 1340'32's. Ice flow toward upper left.

that all the classical concepts of geosynclinal development which were conceived in the Alps and the Appalachian Mountains are applicable to this great Late Precambrian-Cambrian geosynclinal and tectonic cycle. Every major feature is represented: extent and width of the same order, subdivisions into engeosynclinal and miogeosynclinal basins with their appropriate facies, both sedimentary and volcanic, tectonic lands and islands, a marginal neritic shelf facies which has been only slightly affected by the tectonic revolution, and, last but not least, large nappes in one of the foreland troughs. The only major feature that is absent is a 'molasse trough'. Its absence may be a result of the great depth to which erosion has already progressed in the Damara belt."

Nowhere is there any intimation that continental drift played a role in PanAfrican orogeny.

After just two years in Cape Town, Henno was offered the prestigious Chair in Geology and Directorship of the Geological-Paleontological Institute at the University of Göttingen (Germany), a position he held until his retirement in 1975. It was the decisive decade in the scientific life of every geologist of the period, irrespective of their age. The challenge for geologists generally was the plate tectonics paradigm, a creation of marine geophysics; for Henno it was its implications for the Damara belt. He organized a largely Göttingen-based research program established to compare the Variscan (late Paleozoic) belt of central Europe and the Damara belt, as exam- ples of 'intracontinental' fold belts (Martin and Eder 1983). Having concluded in Namibia that the Damara belt was essentially indistinguishable from classic Phanerozoic orogens, he fell in with a group in Germany who thought that the development of Phanerozoic orogens did not involve oceanic lithosphere.

In September 1970, Preston Cloud invited Henno to participate in the 3rd Penrose Conference of the Geological Society of America, held in the Medicine Bow Mountains of Wyoming, to "ascertain the main facts and views about the early lithospheric evolution of North America and to place them in a global context" (Cloud 1971). Henno was

fawned over by the cream of American geologists-Jim Gilluly, Phil King, Sam Goldich, Al Engel, Lee Silver-such was his reputation. Also at the conference was a Canadian geologist less than half Henno's age. Like Henno, he had found a Proterozoic geosyncline that was strikingly similar to Phanerozoic ones in its stratigraphic and structural development (Hoffman et al. 1970). In a plate tectonic interpretation, the geosyncline was a west-facing continental margin that originated through continental breakup in geon 20 and closed by collisional and/or accretionary processes in geon 18 (Hoffman et al. 2011; Hoffman 2012). Plate tectonics or not, the fold belt in the east arm of Great Slave Lake presented a problem. It trends into the interior of the
Archean craton at a high angle to the geosyncline; it is floored by Archean crust and contains (it was thought) only broad upright folds and highangle faults; yet it records the complete stratigraphic development of the geosyncline to the west, along with intermittent igneous activity throughout its history. The Canadian had recently read a paper (Salop and Scheinmann 1969) describing the Russian concept of 'aulacogens', old rifts that merge with craton-encircling geosynclines like the spokes of a wheel. He applied it to the Great Slave fold belt (Hoffman 1971; Fraser et al. 1972) and apparently spoke about it at the Penrose Conference in Wyoming. Years later, when horizontally-directed megastructures (nappes) were found on the lower plate of the Great Slave and associated fold belts (Hoffman et al. 1977; Tirrul 1985; Tirrul and Grotzinger 1990), and a $>1,000$-km-long magmatic arc was recognized on the upper plate (Bostock et al. 1987; van Breemen et al. 1987a, b), the aulacogen concept went out the window for the Great Slave fold belt (Hoffman 1987).

The Göttingen research program comparing the Variscan and Damaran fold belts culminated with the publication of 40 papers in an impressive 945-page volume, entirely in English, with standardized and professionally drafted figures (Martin and Eder 1983). (An additional 7 papers by 


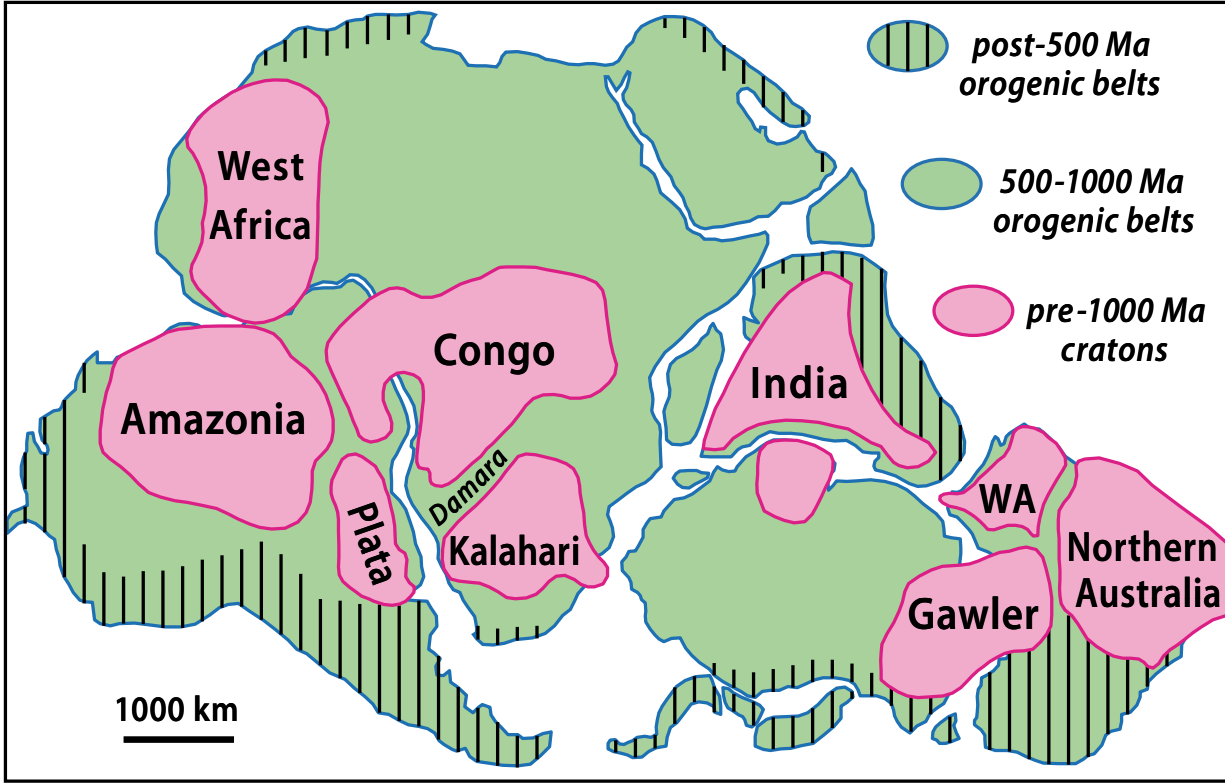

Figure 14. Cratons (pre-1000 Ma) and orogenic belts of the Gondwana megacontinent (modified after Gray et al. 2010).

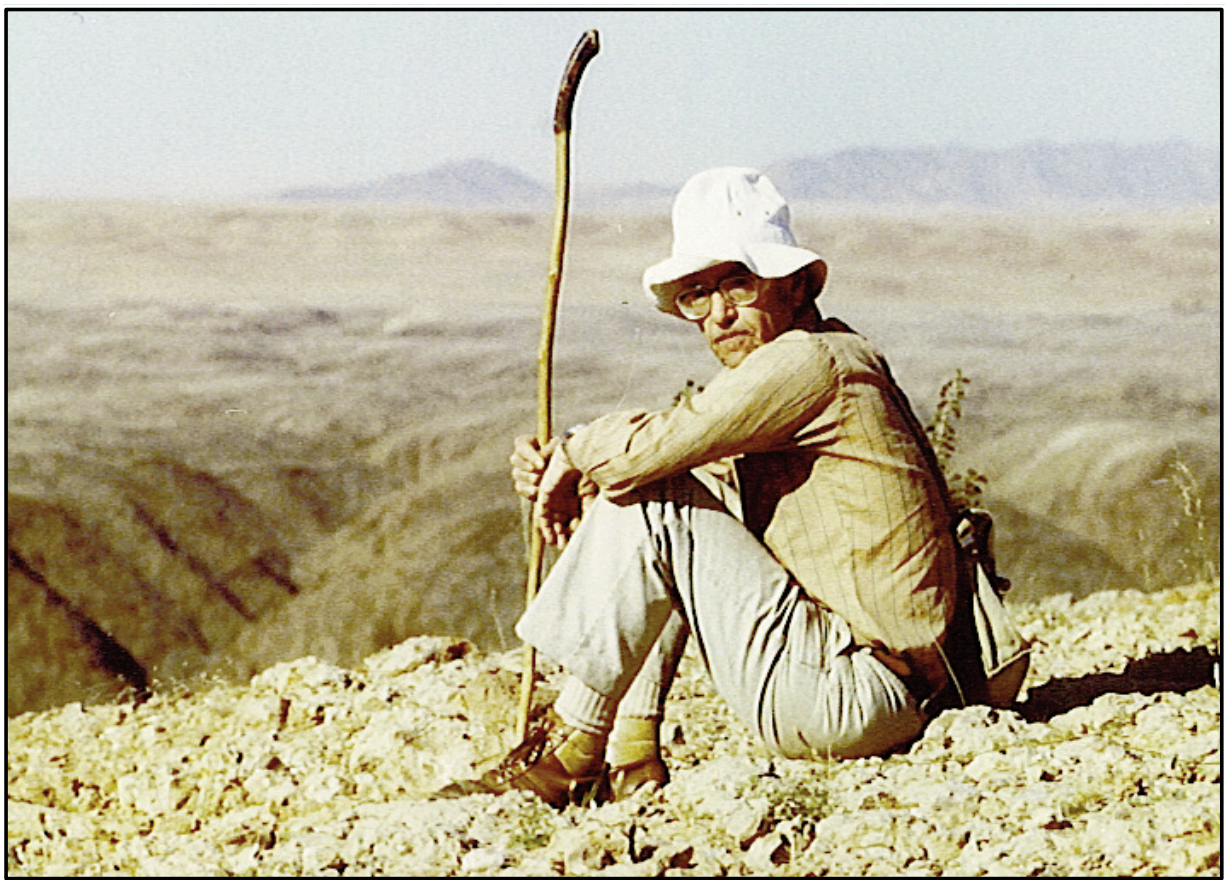

Figure 15. Henno Martin, age 77, on the terrace above his first 1940 campsite with Hermann Korn (compare with Fig. 8), during his last trip to Namibia in 1987. Photograph: Dudley Corbett.

the Göttingen group appeared the same year in a volume on the Damara Orogen alone (Miller 1983a).) In the Variscan half of the big book, there is no mention of the possible involvement of oceanic lithosphere. The Damara half of the book ends with a critical discussion of alternative geodynamic models (Martin 1983). Henno, now 73 , discusses three classes of models: (1) intracratonic models, including aulacogens that undergo spontaneous lithospheric delamination (Martin and Porada 1977a; Kröner 1982), an idea that goes back to Daly (1926); (2) models involving subduction of narrow (Red Sea-type) oceans (Miller 1983b); and (3) models involving the closure of 'wide' ocean basins (Barnes and Sawyer 1980; Kasch 1983).
Henno includes the western Alps in the third category, although it involved an ocean too narrow to generate a magmatic arc when it was subductedunlike the Damara orogen (de Kock et al. 2000). Henno finds none of the models satisfactory, although his objections are not lethal to any (Martin 1983). In the end, it is clear that the aulacogen model is his preferred interpretation of the Damara orogen (see also Martin and Porada 1977a, b). Despite his support for MesozoicCenozoic continental drift, Henno never reconciled himself to PaleozoicProterozoic plate tectonics.

Henno's last paper on Damaran geology concerns the mixtites of central and northern Namibia (Martin et al. 1985). Cogently, he had previously argued that they were likely to be glacial in origin because undoubted glacial deposits occur in southern Namibia at comparable stratigraphic levels (Martin 1965a, b). With Göttingen colleagues, his new verdict is that none of the purported glacial mixtites in central and northern Namibia (Gevers 1931; le Roex 1941) have diagnostic glacial features, except possibly those in the Kaoko Belt, which were not revisited. All are better interpreted, he concludes, as submarine mass-flow deposits, possibly triggered by glacioeustatic changes (Martin et al. 1985). Henno's recantation makes for sad reading in light of recent studies by specialists showing unambiguous evidence for dynamic grounded ice in the Chuos (Le Heron et al. 2013) and Ghaub (Domack and Hoffman 2011) formations of the Otavi fold belt (Fig. 2). Accompanied by his wife Ilse, Henno continued to do field work in Namibia until 1987 (Fig. 15), astounding companions on field trips with his total recall of outcrops visited decades before (Miller and Weber 2000). Normally reserved, except when geology was the subject, the gifted story teller of The Sheltering Desert would resurface in the light of the desert campfire. The human condition, from his unique perspective, is the subject of his final book, Menschbeit auf dem Prüfstand (Mankind on the Test Range), which has yet to be translated from German (Martin 1992). Blind in his last years, Henno Martin died in Göttingen in January 1998 at the age of 87 . 
Namibia, now a country of 2 million people, finally gained independence as a multi-racial representative democracy on March 21, 1990. As with neighbouring Botswana, it has been politically stable and economically independent ever since. Mineral exports generate over half of the nation's foreign-exchange earnings (and $8 \%$ of GDP), a fact reflected in the modernity of its Geological Survey. Founding President Sam Nujoma retired in 2005 after the constitutionally mandated limit of two elected terms in office. He then enrolled at the University of Namibia and in 2009, at age 80, he attained a Master's degree, in Geology, supervised by the current director of the Geological Survey of Namibia.

\section{REFERENCES}

Bailey, R.A., Smith, R.L., and Ross, C.S., 1969, Volcanic rocks in the Jemez Mountains, New Mexico: United States Geological Survey, Bulletin 1274-P, 29 p.

Barnes, S.-J., and Sawyer, E.W., 1980, An alternative model for the Damara mobile belt: ocean crust subduction and continental convergence: Precambrian Research, v. 13, p. 297-336, http://dx.doi.org/10.1016/03019268(80)90048-0.

Blanco, G., Rajesh, H.M., Germs, G.J.B., and Zimmermann, U., 2009, Chemical composition and tectonic setting of chromian spinels from the EdiacaranEarly Paleozoic Nama Group, Namibia: The Journal of Geology, v. 117, p. 325-341, http://dx.doi.org/10.1086/597366.

Blanco, G., Germs, G.J.B., Rajesh, H.M., Chemale, Jr., F., Dussin, I.A., and Justino, D., 2011, Provenance and paleogeography of the Nama Group (Ediacaran to early Palaeozoic, Namibia): Petrography, geochemistry and U-Pb detrital zircon geochronology: Precambrian Research, v. 187, p. 15-32, http://dx.doi.org/10.1016/j.precamres.2011.02.002.

Bostock, H.H., van Breemen, O., and Loveridge, W.D., 1987, Proterozoic geochronology in the Taltson Magmatic Zone, N.W.T., in Radiogenic Age and Isotopic Studies: Geological Survey of Canada, Paper 87-2, p. 73-80.

Bridgman, J.M., 1981, The Revolt of the Hereros: University of California Press, Berkeley, 184 p.
Butler, R.W.H., and Paton, D.A., 2010, Evaluating lateral compaction in deepwater fold and thrust belts: How much are we missing from 'nature's sandbox"?: GSA Today, v. 20, p. 4-10, http://dx.doi.org/10.1130/GSATG77 A.1.

Cloos, H., 1954, Conversations with the Earth: the Autobiography of a Geologist (translated from German by E.B. Garside): Routledge \& Kegan Paul, London, 427 p.

Cloud, P., 1971, The Precambrian: Science, v. 173 , p. $851-854$, http://dx.doi.org/ 10.1126/science.173.3999.851.

Clough, C.T., Maufe, H.B., and Bailey, E.B., 1909, The cauldron-subsidence of Glen Coe, and the associated igneous phenomena: Quarterly Journal of the Geological Society, v. 65, p. 611-678, http://dx.doi.org/10.1144/GSL.JGS.1 909.065.01-04.35.

Daly, R.A., 1926, Our Mobile Earth: Charles Scribner's Sons, New York, $342 \mathrm{p}$.

de Kock, G.S., 1992, Forearc basin evolution in the Pan-African Damara Belt, central Namibia: the Hureb formation of the Khomas zone: Precambrian Research, v. 57, p. 169-194, http://dx.doi.org/10.1016/03019268(92)90001-5.

de Kock, G.S., Eglington, B., Armstrong, R.A., Harmer, R.E., and Walraven, F., 2000, $\mathrm{U}-\mathrm{Pb}$ and $\mathrm{Pb}-\mathrm{Pb}$ ages of the Naauwpoort rhyolite, Kawakeup leptite and Okongava Diorite: implications for the onset of rifting and of orogenesis in the Damara belt, Namibia: Geological Survey of Namibia, Communications, 12, p. 81-88.

Diehl, M., 1990, Geology, mineralogy, geochemistry and hydrothermal alteration of the Brandberg alkaline complex, Namibia: Geological Survey of Namibia, Memoir 10, 55 p.

Domack, E.W., and Hoffman, P.F., 2011, An ice grounding-line wedge from the Ghaub glaciation $(635 \mathrm{Ma})$ on the distal foreslope of the Otavi carbonate platform, Namibia, and its bearing on the Snowball Earth hypothesis: Geological Society of America Bulletin, v. 123, p. 1448-1477, http://dx.doi.org/10.1130/B30217.1.

du Toit, A.L., 1927, A geological comparison of South America with South Africa: Carnegie Institution of Washington, Publication 381, 158 p.

du Toit, A.L., 1937, Our Wandering Continents: Hafner, New York, 366 p.

Eagles, G., 2007, New angles on South Atlantic opening: Geophysical Journal International, v. 168, p. 353-361, http://dx.doi.org/10.1111/j.1365-

246X.2006.03206.x.

Fraser, J.A., Hoffman, P.F., Irvine, T.N., and Mursky, G., 1972, The Bear Province, in Price, R.A., and Douglas, R.J.W., eds., Variations in Tectonic Styles in Canada: Geological Association of Canada, Special Publication 11, p. 453-504.

Gevers, T.W., 1931, An ancient tillite in South-West Africa: Geological Society of South Africa, Transactions, v. 34, p. $1-17$.

Gray, D.R., Foster, D.A., Meert, J.G., Goscombe, B.D., Armstrong, R., Trouw, R.A.J., and Passchier, C.W., 2010, A Damara orogen perspective on the assembly of southwestern Gondwana, in Pankhurst, R.J., Trouw, R.J., Brito Neves, B.B., and de Wit, M.J., eds., West Gondwana: Pre-Cenozoic Correlations Across the South Atlantic Region: Geological Society of London, Special Publication 294, p. 257-278.

Grotzinger, J.P., Bowring, S.A., Saylor, B.Z., and Kaufman, A.J., 1995, Biostratigraphic and geochronologic constraints on early animal evolution: Science, v. 270, p. 598-604, http:/ /dx.doi.org/10.1126/science. 270.5236 .598 .

Harland, W.B., 1964a, Evidence of late Precambrian glaciation and its significance, in Nairn, A.E.M., ed., Problems in Palaeoclimatology: Interscience, London, p. 119-149.

Harland, W.B., 1964b, Critical evidence for a great infra-Cambrian glaciation: Geologische Rundschau, v. 54, p. 45-61, http://dx.doi.org/10.1007/BF018211 69.

Harland, W.B., and Rudwick, M.J.S., 1964, The great infra-Cambrian ice age: Scientific American, v. 211, p. 28-36, http://dx.doi.org/10.1038/scientificamerican0864-28.

Hartnady, C.J., 1978, The stratigraphy and structure of the Naukluft nappe complex: Precambrian Research Unit, University of Cape Town, Annual Report 14-15, p. 163-170.

Hoffman, P.F., 1971, Aulacogenes and orthogeosynclines in the lower Proterozoic of the northwestern Canadian Shield (abstract): Geological Society of America, Programs with Abstracts, v. 3, p. 601.

Hoffman, P.F., 1987, Continental transform tectonics, Great Slave Lake shear zone (ca 1.9 Ga), northwest Canada: Geology, v. 15, p. 785-788, http://dx.doi.org/10.1130/00917613(1987)15<785:CTTGSL>2.0.CO; 2. 
Hoffman, P.F., 1991, Did the breakout of Laurentia turn Gondwanaland insideout?: Science v. 252, p. 1409-1412, http://dx.doi.org/10.1126/science.252.5011.1409.

Hoffman, P.F., 2012, The tooth of time: How do passive margins become active? Geoscience Canada, v. 39, p. 67-73.

Hoffman, P.F., Fraser, J.A., and McGlynn, J.C., 1970, The Coronation Geosyncline of Aphebian age, District of Mackenzie, in Baer, A., ed., Symposium on Basins and Geosynclines of the Canadian Shield: Geological Survey of Canada, Paper 70-40, p. 201-212.

Hoffman, P.F., Bell, I.R., Hildebrand, R.S., and Thorstad, L., 1977, Geology of the Athapuscow Aulacogen, east arm of Great Slave Lake, District of Mackenzie: in Report of Activities, Part A, Geological Survey of Canada, Paper 77-1A, p. 117-129.

Hoffman, P.F., Bowring, S.A., Buchwaldt, R., and Hildebrand, R.S., 2011, Birthdate for the Coronation paleocean: age of initial rifting in Wopmay orogen, Canada: Canadian Journal of Earth Sciences, v. 48, p. 281-293, http://dx.doi.org/10.1139/E10-038.

Hoffmann, K.H., 1983, Lithostratigraphy and facies of the Swakop Group of the Southern Damara Belt, SWA/Namibia, in Miller, R.McG., ed., Evolution of the Damara Orogen of South West Africa/Namibia: Geological Society of South Africa, Special Publication 11, p. 43-63.

Hoffmann, K.H., 1987, Application of tectonostratigraphic terrane analysis in the Damara Province of central and northern Namibia (abstract), in A.L. du Toit Golden Jubilee Conference on Tectonostratigraphic Terrane Analysis, Abstract Volume: Royal Society and Geological Society of South Africa, Cape Town, p. 25-27.

Hoffmann, K.H., 1989, New aspects of lithostratigraphic subdivision and correlation of late Proterozoic to early Cambrian rocks of the southern Damara Belt and their correlation with the central and northern Damara Belt and the Gariep Belt: Geological Survey of Namibia, Communications, 5, p. 59-67.

Hoffmann, K.H., 1991, Stratigraphic analysis of eustatic and tectonic effects on subsidence and deposition during convergent margin sedimentation in the Damara Belt and adjacent cratonic foreland basins, in Terra Nova, Abstracts Supplement 3, p. 15-16.

Holmes, A., 1963, Introduction, in Rankama, K., ed., The Precambrian vol. 1:
Wiley Interscience, New York, p. xixxiv.

Johnson, S.D., Poujol, M., and Kisters, A.F.M., 2006, Constraining the timing and migration of collisional tectonics in the Damara Belt, Namibia: U-Pb zircon ages for the syntectonic Salemtype Stinkbank granite: South African Journal of Geology, v. 109, p.

611-624

http://dx.doi.org/10.2113/gssajg.109. 4.611.

Kasch, K.W., 1983, Continental collision, suture progradation and thermal relaxation: a plate tectonic model for the Damara Orogen in central Namibia, in Miller, R.McG., ed., Evolution of the Damara Orogen of South West Africa/Namibia: Geological Society of South Africa, Special Publication 11, p. 423-429.

Knoll, A.H., 1991, End of the Proterozoic Eon: Scientific American, v. 265, p. 64-73, http://dx.doi.org/10.1038/scientificamerican1091-64.

Knoll, A.H., and Walter, M.R., 1992, Latest Proterozoic stratigraphy and Earth history: Nature, v. 356, p. 673-678, http://dx.doi.org/10.1038/356673a0.

Kokelaar, B.P., and Moore, I.D., 2006, Classical areas of British geology: Glencoe caldera volcano, Scotland: British Geological Survey, Keyworth, Nottingham, $127 \mathrm{p}$.

Korn, H., 1938, Schichtung und absolute Zeit. Bewegungen, Schichtenaufbau und Sedimentationsgeschwindigkeiten in einer variszischen Mulde (Bedding and absolute time: sediment transport, stratification and accumulation rate in a Variscan trough): Nenes Jabrbuch für Mineralogie, v. $74 A$, p. $50-186$.

Korn, H., 1996, Zwiegespräch in der Wüste: Briefe und Aquarelle aus dem Exil 1935 1946 (Meditations in the Desert: Letters and Watercolours from Exile 1935-1946): Klaus Hess Verlag, Göttingen, $158 \mathrm{p}$.

Korn, H., and Martin, H., 1954, The Messum igneous complex in South-West Africa: Geological Society of South Africa, Transactions, v. 57, p. 83-124.

Korn, H., and Martin, H., 1959, Gravity tectonics in the Naukluft Mountains of South West Africa: The Geological Society of America Bulletin, v. 70, p. 1047-1078, http:/ /dx.doi.org/10.1130/00167606(1959)70[1047:GTITNM]2.0.CO; 2.

Kröner, A., 1982, Rb-Sr geochronology and tectonic evolution of the PanAfrican Damara belt of Namibia, southwestern Africa: American Journal of Science, v. 282, p. 1471-1507, http://dx.doi.org/10.2475/ajs.282.9.1 471.

Kukla, P.A., and Stanistreet, I.G., 1991, Record of the Damaran Khomas Hochland accretionary prism in central Namibia: Refutation of an "ensialic" origin of a Late Proterozoic orogenic belt: Geology, v. 19, p. 473-476, http://dx.doi.org/10.1130/00917613(1991)019<0473:ROTD$\mathrm{KH}>2.3 . \mathrm{CO} ; 2$.

Le Heron, D.P., Busfield, M.E., and Kamona, F., 2013, An interglacial on snowball Earth? Dynamic ice behaviour revealed in the Chuos Formation, Namibia: Sedimentology, v. 60, p. 411-427, http://dx.doi.org/10.1111/j.13653091.2012.01346.x.

le Roex, H.D., 1941, A tillite in the Otavi Mountains, S.W.A.: Geological Society of South Africa, Transactions, v. 44, p. 207-218.

Linnemann, U., and Romer, R.L., eds., 2010, Pre-Mesozoic Geology of SaxoThuringia: From the Cadomian Active Margin to the Variscan Orogeny: Schweizerbart, Stuttgart, 488 p.

Martin, H., 1953, Notes on the Dwyka succession and on some pre-Dwyka valleys in South West Africa: Geological Society of South Africa, Transactions, v. 56, p. $37-41$.

Martin, H., 1961, The hypothesis of continental drift in the light of recent advances of geological knowledge in Brazil and in South West Africa: 7th Alex. du Toit Memorial Lecture, Geological Society of South Africa, Annexures, v. 64, p. 1-47.

Martin, H., 1965a, The Precambrian Geology of South West Africa and Namaqualand: Precambrian Research Unit, University of Cape Town, 159 p.

Martin, H., 1965b, Beobacbtungen zum Problem der jung-präkambrischen Glazialen Ablagerungen in Südwestafrika (Observations concerning the problem of the late Precambrian glacial deposits in South West Africa): Geologische Rundschau, v. 54, p. 115-127, http://dx.doi.org/10.1007/BF018211 73.

Martin, H., 1968a, Paläomorphologische Formelemente in den Landschaften SüdwestAfrikas: Geologische Rundschau, v. 58, p. 121-128, http://dx.doi.org/10.1007/BF018205 98.

Martin, H., 1968b, A critical review of the evidence for a former direct connection of South America with Africa, in Fittkau, E.J., Illies, J., Klinge, H., Schwabe, G.H., and Sioli, H., eds., Geogeography and Ecology in South 
America: Dr. W. Junk N.V., The Hague, p. 25-53.

Martin, H., 1974, Damara rocks as nappes on the Naukluft Mountains, South West Africa, in Kröner, A., ed., Contributions to the Geology of Southern Africa: A Volume in Honour of John de Villiers: Precambrian Research Unit, University of Cape Town, Bulletins 15, p. 153-165.

Martin, H., 1981, The late Palaeozoic Gondwana glaciation: Geologische Rundschau, v. 70, p. 480-496, http://dx.doi.org/10.1007/BF018221 28.

Martin, H., 1983, Alternative geodynamic models for the Damara orogeny. A Critical Discussion, in Martin, H., and Eder, F.W., eds., Intracontinental Fold Belts: Springer-Verlag, Berlin, p. 913-945, http://dx.doi.org/10.1007/978-3-64269124-9_41.

Martin, H., 1992, Menschbeit auf dem Prüfstand (Mankind on Trial): Springer-Verlag, Berlin, $407 \mathrm{p}$.

Martin, H., 2012, The Sheltering Desert (English translation by Wiliam Kimber, 1957): two books, Augsburg, Germany, $370 \mathrm{p}$.

Martin, H., and Eder, F.W., eds., 1983, Intracontinental Fold Belts: SpringerVerlag, Berlin, 945 p., http://dx.doi.org/10.1007/978-3-64269124-9.

Martin, H., and Porada, H., 1977a, The intracratonic branch of the Damara orogen in South West Africa I. Discussion of geodynamic models: Precambrian Research, v. 5, p. 311-338, http://dx.doi.org/10.1016/03019268(77)90039-0.

Martin, H., and Porada, H., 1977b, The intracratonic branch of the Damara orogen in South West Africa II. Discussion of relationships with the PanAfrican mobile belt system: Precambrian Research, v. 5, p. 339-357, http://dx.doi.org/10.1016/03019268(77)90040-7.

Martin, H., Porada, H., and Wittig, R., 1983, The root zone of the Naukluft Nappe Complex: geodynamic implications, in Martin, H., and Eder, F.W., eds., Intracontinental Fold Belts: Springer-Verlag, Berlin, p. 679-698, http://dx.doi.org/10.1007/978-3-64269124-9_27.

Martin, H., Porada, H., and Walliser, O.H., 1985, Mixtite deposits of the Damara Sequence, Namibia, problems of interpretation: Palaeogeography, Palaeoclimatology, Palaeoecology, v. 51, p. 159-196, http://dx.doi.org/10.1016/0031-
0182(85)90084-7.

Martínez Catalán, J.R., 2011, Are the oroclines of the Variscan belt related to late Variscan strike-slip tectonics? Terra Nova, v. 23, p. 241-247, http://dx.doi.org/10.1111/j.13653121.2011.01005.x.

Mendelsohn, J., Jarvis, A., Roberts, C., and Robertson, T., 2002, Atlas of Namibia: A Portrait of the Land and its People: David Philip, Cape Town, South Africa, 200 p.

Miller, R.McG., ed., 1983a, Evolution of the Damara Orogen of South West Africa/Namibia: Geological Society of South Africa, Special Publication 11, $515 \mathrm{p}$.

Miller, R.McG., 1983b, Tectonic implications of the contrasting geochemistry of Damaran mafic volcanic rocks, South West Africa/Namibia, in Miller, R.McG., ed., Evolution of the Damara Orogen of South West Africa/Namibia: Geological Society of South Africa, Special Publication 11, p. 115-138.

Miller, R.McG., 1983c, The Pan-African Damara Orogen of South West Africa/Namibia, in Miller, R.McG., ed., Evolution of the Damara Orogen of South West Africa/Namibia: Geological Society of South Africa, Special Publication 11, p. 431-515.

Miller, R.McG., 2008, The Geology of Namibia Volume 2, Neoproterozoic to Lower Paleozoic: Geological Survey, Windhoek, Namibia, 515 p.

Miller, R.McG., and Weber, K, 2000, Henno Martin, in Miller, R.McG., ed., Special Issue: Henno Martin Commemorative Volume: Geological Survey of Namibia, Communications, 12 , p. v-vi.

Münch, H.G., 1978, Das Schmiermittel an der Basis der Naukluft-Decke, Südwestafrika: Zeitschrift der Deutschen Geologischen Gesellschaft, v. 129, p. 7-13.

Pakenham, T., 1991, The Scramble for Africa: White Man's Conquest of the Dark Continent from 1876 to 1912: Avon Books, New York, 738 p.

Passchier, C.W., Trouw, R.A.J., Ribeiro, A., and Paciullo, F.V.P., 2002, Tectonic evolution of the southern Kaoko belt, Namibia: Journal of African Earth Sciences, v. 35, p. 61-75, http://dx.doi.org/10.1016/S08995362(02)00030-1.

Porada, H., 1983, Geodynamic model for the geosynclinal development of the Damara Orogen, Namibia, South West Africa, in Martin, H., and Eder, F.W., eds., Intracontinental Fold Belts: Springer-Verlag, Berlin, p. 503-541, http:/ /dx.doi.org/10.1007/978-3-64269124-9_22.
Porada, H., 1989, Pan-African rifting and orogenesis in southern to equatorial Africa and eastern Brazil: Precambrian Research, v. 44, p. 103-136, http://dx.doi.org/10.1016/03019268(89)90078-8.

Salop, L.I., and Scheinmann, Yu.M., 1969, Tectonic history and structures of platforms and shields: Tectonophysics, v. 7 , p. $565-597$, http://dx.doi.org/10.1016/00401951(69)90031-6.

Schermerhorn, L.J.G., and Stanton, W.I., 1963, Tilloids in the West Congo geosyncline: Quarterly Journal of the Geological Society, v. 119, p. 201-241, http://dx.doi.org/10.1144/gsigs.119.1. 0201.

Schneider, G.I.C., 2000, The history of the Geological Survey of Namibia, in Miller, R.McG., ed., Special Issue: Henno Martin Commemorative Volume: Geological Survey of Namibia, Communications, 12, p.1-12, PMid:10862994.

Sederholm, J.J., 1907, Om granit och gneis, deras uppkomst, uppträdande och utbredning inom urberget $i$ Fennoskandia (English summary: On granite and gneiss, their origin, relations and occurrence in the pre-Cambrian complex of FennoScandia): Bulletin de la Commission géologique de Finlande, 23, 118 p.

Smith, R.L., and Bailey, R.A., 1968, Resurgent cauldrons, in Coats, R.R., Hay, R.L., and Anderson, C.A., eds., Studies in Volcanology: Geological Society of America, Memoir 116, p. 613-662.

Swart, R., 1992, The sedimentology of the Zerrissene turbidite system, Damara Orogen, Namibia: Geological Survey of Namibia, Memoir 13, 54 p.

Tirrul, R., 1985, Nappes in the Kilohigok Basin and their relation to the Thelon Tectonic Zone, in Current Research, Part A: Geological Survey of Canada, Paper 85-1A, p. 407-420.

Tirrul, R., and Grotzinger, J.P., 1990, Early Proterozoic collisional orogeny along the northern Thelon tectonic zone, Northwest Territories, Canada: Evidence from the foreland: Tectonics, $v$. 9, p. 1015-1036, http://dx.doi.org/10.1029/TC009i005 p01015.

van Breemen, O., Henderson, J.B., Loveridge, W.D., and Thompson, P.H., 1987a, U-Pb zircon and monazite geochronology and zircon morphology of granulites and granite from the Thelon Tectonic Zone, Healey Lake and Artillery Lake map areas, N.W.T., in Radiogenic Age and Isotopic Studies, Report 1: Geological Survey of Canada, Paper 87-2, p. 101-110. 
van Breemen, O., Thompson, P.H., Hunt, P.A., and Culshaw, N., 1987b, U-Pb zircon and monazite geochronology from the northern Thelon Tectonic Zone, District of Mackenzie, in Radiogenic Age and Isotopic Studies, Report 1: Geological Survey of Canada, Paper 87-2, p. 81-93.

Wallace, M. (with J. Kinahan), 2011, A History of Namibia: From the Beginning to 1990: Jacana, Aukland Park, South Africa, $451 \mathrm{p}$.

Weber, K., 1998, Memorial to Henno Martin, 1910-1998: Geological Society of America, Memorials, 29, p. 71-73.

Wegmann, C.E., 1929, Über die alpine Tektonik, und ibre Anwendung auf das Grundgebirge Finnlands (On Alpine tectonics and its application to the primitive rocks of Finland): Bulletin de la Commission géologique de Finlande, 85, p. 49-53. 